\title{
Insulin stimulates skeletal growth in vivo and in vitro - comparison with growth hormone in rats
}

\author{
E.Heinze ${ }^{1}$, U. Vetter ${ }^{1}$ and K. H. Voigt ${ }^{2}$ \\ ${ }^{1}$ Department of Pediatrics University of Ulm and ${ }^{2}$ Department of Physiology, University of Marburg/Lahi, FRG
}

\begin{abstract}
Summary. The effect of insulin on skeletal growth was examined by (1) systemic injection, (2) local administration into the tibia growth plate and (3) in vitro by use of chondrocytes in culture. (1) Male rats, body weight $60-75 \mathrm{~g}$, were hypophysectomised. One week after the operation, the animals were divided into three groups. Group A received intraperitoneally saline, group B insulin $\left(5-30 \mathrm{U} \cdot \mathrm{kg}^{-1} \cdot \mathrm{day}^{-1}\right)$ and group C human growth hormone $(250 \mu \mathrm{g} / \mathrm{kg} /$ day $)$ for the following 10 days. In addition, on day 10 the rats were injected with $10 \mu \mathrm{Ci} 35$-S-sulfate intraperitoneally. Twenty-four $\mathrm{h}$ later in the non-fasting state plasma glucose, insulin, somatomedin activity (porcine assay), body weight, nose-rump length, width of the tibia growth plate, and the 35-S-sulfate incorporation into rib cartilage were determined. Compared to saline, growth hormone and insulin treatment significantly enhanced body weights, nose-rumb lengths, the widths of the proximal tibia growth plates and the incorporation of sulfate into rib cartilage. For the three skeletal growth parameters, growth hormone was more effective than insulin, while body weights did not differ after insulin or growth hormone treatment. So-
\end{abstract}

matomedin activity $(\mathrm{U} / \mathrm{ml})$ was low in group $\mathrm{A}(0.39 \pm 0.04$, $n=9$, Mean \pm SEM $)$ and group $\mathrm{B}(0.34 \pm 0.08, n=8)$ and high in the growth hormone treated group $\mathrm{C}(0.90 \pm 0.09, n=7$; $\mathrm{p}<0.002$ ). (2) To test the possibility that insulin might directly augment skeletal growth, insulin $(80 \mathrm{mU})$ was injected into the proximal tibia growth plate of one leg and saline into the cartilage zone of the other leg. Insulin treatment significantly increased the width of the cartilage zones. Insulin: $211 \pm 22 \mu \mathrm{m}$, saline $200 \pm 22 \mu \mathrm{m}$, (Mean $\pm \mathrm{SD}, n=6, p<0.05$ ). (3) Addition of human biosynthetic insulin and growth hormone to the culture medium increased colony formation of chondrocytes in a bell-shaped fashion. A plateau in colony formation was reached with $3.1-6.25 \mathrm{ng} / \mathrm{ml}$ insulin and $25-50 \mathrm{ng} / \mathrm{ml}$ growth hormone, but with larger dosages of both hormones, the effect was diminished. The results suggest that insulin might stimulate postnatal skeletal growth by a direct effect on the target cells.

Key words: Skeletal growth, somatomedin, insulin, growth hormone, rats.
In 1953, Salter and Best injected hypophysectomised rats with a long acting insulin preparation and demonstrated a definite augmentation of skeletal growth, which was of the same magnitude as after growth hormone. This was the first experimental evidence that insulin might act as a growth hormone [1]. At that time, it was unknown whether insulin enhanced skeletal growth directly or via the generation of growth factors. Growth hormone, insulin-like growth factors, and insulin are closely related with each other. In hypophysectomised rats, insulin and the insulin-like growth factors, the somatomedins, dropped to low or undetectable levels. Treatment of the animals with appropriate doses of growth hormone increased both serum insulin and the somatomedins towards normal concentrations [2-5]. In contrast, treatment of hypophysectomised diabetic rats with high doses of growth hormone only slightly augmented serum somatomedin concentrations [6]. In pancreatectomised diabetic dogs, the serum somatomedin activity was un- measurably low despite very high serum growth hormone concentrations, but insulin treatment of the diabetic animals normalised the insulin-like growth factors [7]. As to the effect of the three hormones on somatic growth, one hypothesis claims that the action growth hormone on the skeleton is mediated by the somatomedins $[8,9]$. Recently, however, it was shown that growth hormone in vivo and in vitro may directly augment skeletal growth $[10,11]$. Finally, for insulin, it has been repeatedly shown that the hormone, at least in pharmacological concentrations, stimulated cartilage metabolism in vitro [12].

The aim of the present study was to compare the reported systemic effect of insulin on longitudinal growth [1] with a possible local action of the hormone on growth of cartilage in vivo and in vitro. For comparison, skeletal growth was determined in response to growth hormone. Blood glucose, serum insulin and serum somatomedin activity were measured. 
Table 1. Plasma glucose, plasma insulin and plasma somatomedin activity in hypophysectomised male rats

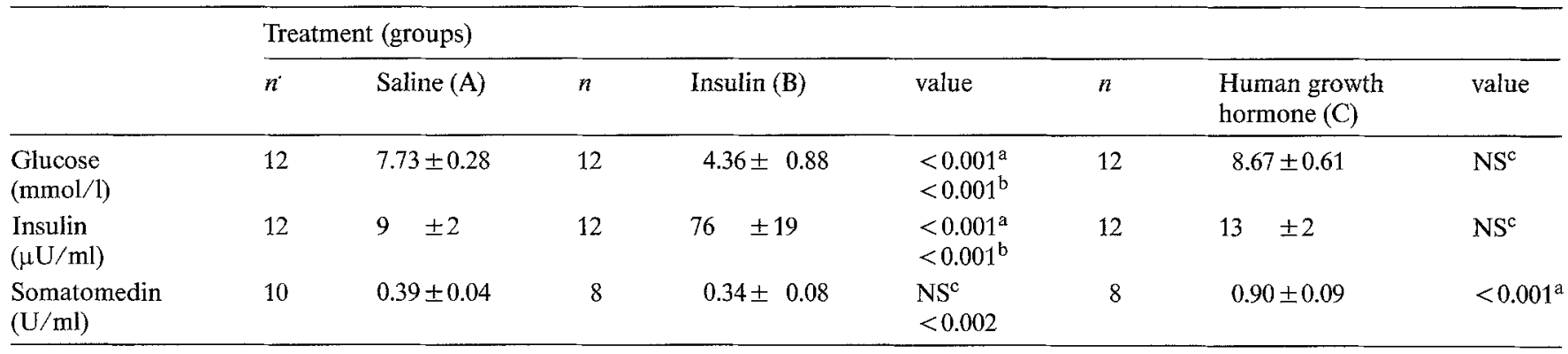

${ }^{\mathrm{a}} p$ versus saline; ${ }^{\mathrm{b}} p$ insulin versus growth hormone; ${ }^{c}$ not significant; $n=$ number of animals; Mean \pm SEM

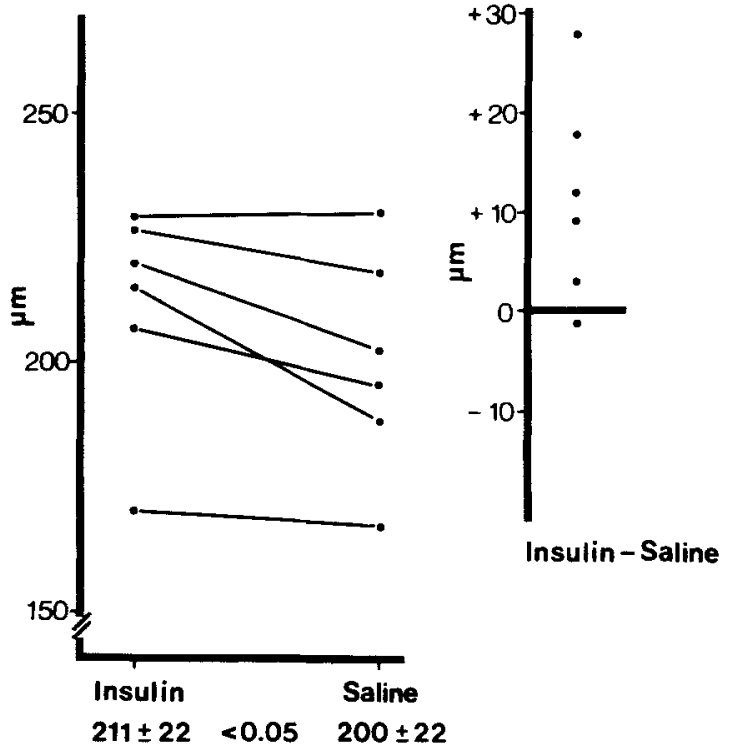

Fig. 1. Skeletal growth after local injection of insulin $(80 \mathrm{mU} / 2 \mu \mathrm{l})$ or saline $(2 \mu l)$ into the proximal tibia cartilage zone of hypophysectomised male rats. Tibia tests were done $48 \mathrm{~h}$ after treatment. Mean $\pm S D$

\section{Materials and methods}

Male Wister rats, body weights $60-75 \mathrm{~g}$, were used. Under general anaesthesia (Nembutal, $40 \mathrm{mg} / 100 \mathrm{~g}$ body weight), the animals were hypophysectomised by a stereotactic transauricular method [14]. The rats had free access to water and food (rat pellets, Altromin, Altrogge, Lippe, FRG). For 3 days after the operation, food was soaked in water. Only hypophysectomised animals with a weight gain within our published values were randomly selected [14]. Rats were studied one week after hypophysectomy. In a first series of experiments, the animals were randomly divided into three groups. On the next 10 days, body weights were determined between 9:00 and 10:00 hours. Afterwards, the animals were injected i.p. with normal saline, human growth hormone $(\mathrm{GH})\left(250 \mu \mathrm{g} \cdot \mathrm{kg}^{-1} \cdot \mathrm{day}^{-1}\right)$ or porcine insulin (Ultralente, Novo, Copenhagen, Denmark). As reported by Salter and Best [1], depending on weight gain, the dose of insulin was increased from $5 \mathrm{U} \cdot \mathrm{kg}^{-1} \cdot \mathrm{day}^{-1}$ to $30 \mathrm{U} \cdot \mathrm{kg}^{-1} \cdot \mathrm{day}^{-1}$ on the last two days of the experiments. On day 10 at 9:00 hours, all animals received i.p. $10 \mu \mathrm{C} 35-\mathrm{S}$-sulfate (spec. activity $5 \mu \mathrm{Ci} / \mathrm{mg}$ sulfate, Amersham Buchler, Braunschweig, FRG). One day later under general anaesthesia, nose rump length was recorded. Since, in pilot experiments, a high mortality rate of insulin treated hypophysectomised rats was noted after an overnight fast, blood was collected in the non-fasting state from the abdominal aorta, centrifuged and stored at $-20^{\circ} \mathrm{C}$ until analysis. Cartilages from rib 3 to 7 were dissected, dried at room temperature for $20 \mathrm{~h}$ and weighed. Afterwards, the cartilages were dissolved in $0.4 \mathrm{ml}$ concentrated formic acid at $70^{\circ} \mathrm{C}$ for $3 \mathrm{~h}$. Then $10 \mathrm{ml}$ Bray's solution were added, and the radioactivity was counted in a liquid scintillation counter (Isocap 300, Searle, Frankfurt/M, FRG). At random, one tibia of each rat was removed, and the mean width of the proximal epiphyseal cartilage zone was determined at 10 equidistant sites [14]. Plasma glucose was measured with a Beckmann Autoanalyser (Beckman-Instruments, Munich, FRG), insulin radioimmunologically (insik-1-Kit, Isotopen Dienst West, Dreieich, FRG) with rat insulin as the standard and plasma somatomedin activity with the porcine cartilage bioassay [15]. The pooled plasma of 10 male rats, body weights $200 \mathrm{~g}$, was used as standard. By definition, $1 \mathrm{ml}$ of the standard plasma contains $1 \mathrm{U}$ somatomedin.

In a second of experiments, again hypophysectomised were used. Under general anaesthesia, $80 \mathrm{mU}$ insulin (Ultralente, Novo, Copenhagen, Denmark) were injected in a volume of $2 \mu \mathrm{l}$ at random into the proximal tibia growth plate of one leg and $2 \mu \mathrm{I}$ normal saline into the cartilage zone of the other leg [10]. Tibia tests were performed $24 \mathrm{~h}$ later.

In a third series of experiments, cartilage of ribs 3-7 of normal male rats was dissected and cleaned from adherent tissue. Isolation and the cell culture conditions of chondrocytes have been previously reported in detail $[16,17]$. Briefly, cartilage was minced and digested with $0.25 \%(\mathrm{w} / \mathrm{v})$ trypsin and $2 \mathrm{mg} / \mathrm{ml}$ collagenase CLS II Worthington (Seromed-Biochrom AG, West Berlin, FRG). After centrifugation, the sediment was re-suspended in Ham's F-10 medium supplemented with $10 \%$ ( $\mathrm{v} / \mathrm{v}$ ) fetal calf serum, $200 \mathrm{mmol} / 1$ L-glutamin, $0.1 \mathrm{ml}$ minimum essential medium (MEM) vitamins (Seromed). Viability of the cells was determined with trypan blue [18]. The growth of chondrocytes in vitro was determined with a clonal proliferation assay. The culture technique is based on the observation that the use of semi-solid culture medium prevented the sedimentation of the cells and, therefore, enabled proliferating chondrocytes to form colonies. One thousand chondrocytes were incubated in $1 \mathrm{ml}$ BM-WisslerMedium (Boehringer, Mannheim, FRG) supplemented with $5 \%(\mathrm{v} / \mathrm{v})$ heat inactivated fetal calf serum (incubated for $60 \mathrm{~min}$ at $70^{\circ} \mathrm{C}$ ), $40 \mathrm{mg}$ (w/v) gentamycin (BYK-ESSEX, Munich, FRG), $5 \mu 1$ MEM vitamins, $0.1 \mathrm{~mol} / 1$ (v/v) 2-mercaptoethanol, $1.0 \%(\mathrm{~V} / \mathrm{v})$ methylcellulose (Fluka, Buchs, Switzerland), human biosynthetic insulin or growth hormone (E.Lilly, Bad Homburg, FRG). Thge cultures were incubated without medium change for 14 days at $37^{\circ} \mathrm{C}, 5 \% \mathrm{O}_{2}, 5 \% \mathrm{CO}_{2}$ and a $95 \%$ relative humidity. Results are expressed as percent colonies of inserted viable chondrocytes.

\section{Statistical analysis}

The results of the somatomedin determinations were evaluated by standard statistical methods for bioassays [19]. The statistical significance of the results was calculated with Student's paired or unpaired t-test. 
Table 2. Skeletal growth in hypophysectomised male rats

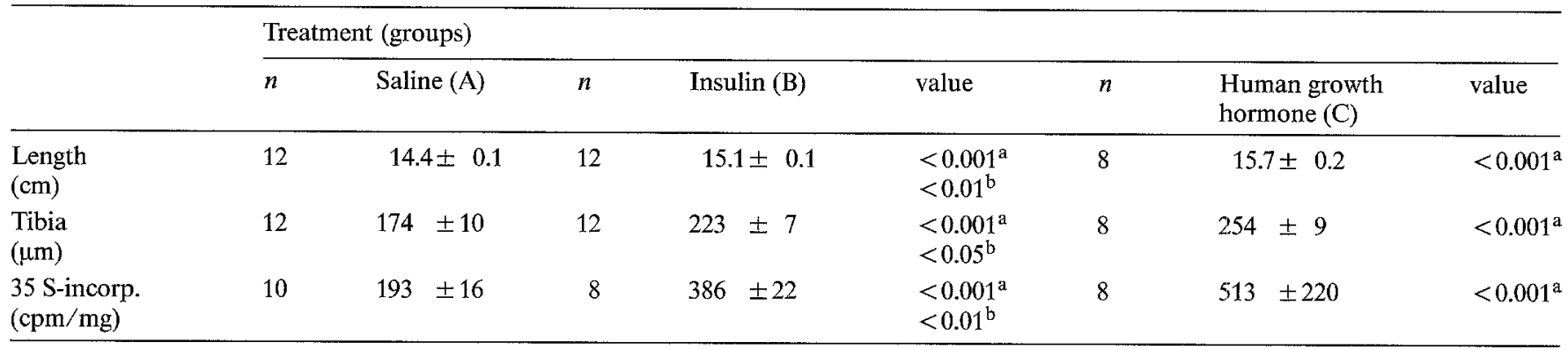

${ }^{\mathrm{a}} p$ versus saline; ${ }^{\mathrm{b}} p$ insulin versus growth hormone; $n=$ number of animals studied; Mean $\pm \mathrm{SEM}$

\section{Results}

Plasma glucose, insulin, and somatomedin activity (Table 1)

Twenty-four $\mathrm{h}$ after the last insulin, growth hormone or saline injections, the determinations were done in plasma samples of non-fasted rats. Insulin-injected rats had significantly lower $(p<0.001)$ plasma glucose and significantly augmented $(p<0.001)$ insulin concentrations compared to saline or growth hormone injected animals. There were no significant differences in glucoseor insulin concentrations after saline or GH treatment. Serum somatomedin activities were equally low in saline- and insulin-treated animals and significantly elevated $(p<0.001)$ after growth hormone.

\section{Body weights}

The animals were weighed each day. At the end of the experiments, the increase of body weight was calculated and expressed as $\mathrm{g}$ weight gain per day. The body weight calculations are as follows - in the saline treated group: $0.7 \pm 0.1 \mathrm{~g},(n=12$, Mean \pm SEM $)$; in the insulin group: $2.1 \pm 0.2 \mathrm{~g},(n=12, p<0.001$ versus saline group and in the GH group: $1.8 \pm 0.2 \mathrm{~g}(n=8, p<0.001$ versus saline) groups. The difference in weight gain between insulin and $\mathrm{GH}$ treated rats was not significant.

\section{Nose-rump length, tibia assay and 35-S-sulfate incorporation into rib cartilage (Table 2)}

Within the three groups of rats with no exception, similar results were obtained for all three skeletal growth parameters. Saline treated hypophysectomised rats showed the lowest growth response. Insulin treatment for 10 days significantly augmented nose-rump length $(p<0.001)$, width of the proximal tibia growth plate $(p<0.001)$ and the sulfate incorporation into rib cartilage $(p<0.001)$ compared to saline treated animals. In comparison to insulin, a further significant increase in skeletal growth was observed after GH treatment: noserump length $(p<0.01)$, tibia growth plate $(p<0.05)$, sulfate incorporation inti rib cartilage $(p<0.01)$.

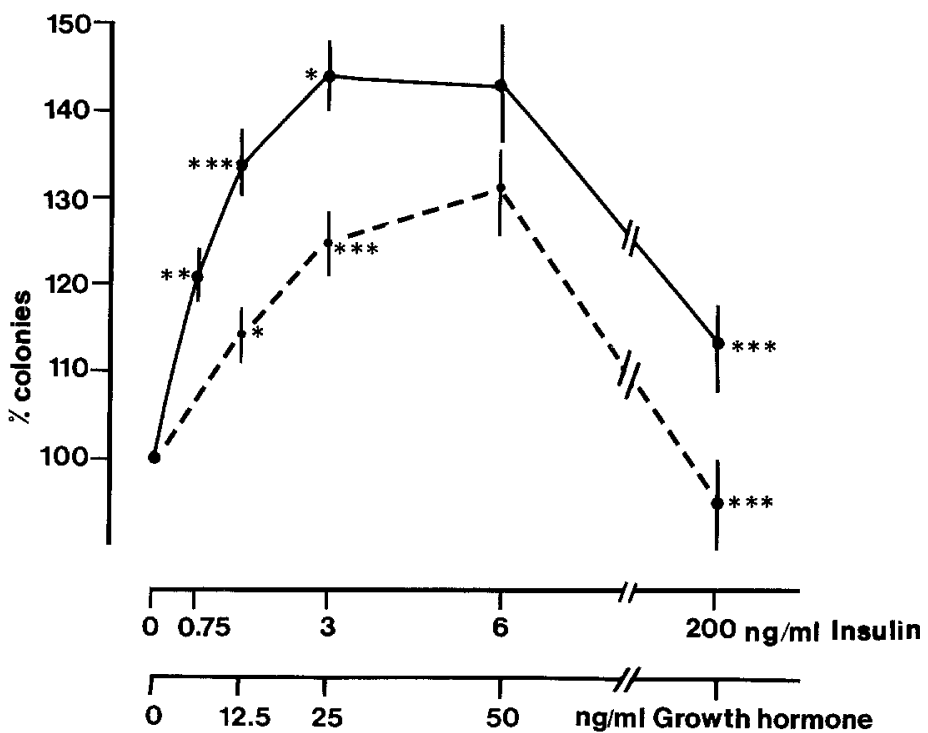

Fig. 2. Colony formation of chondrocytes from normal male rats in response to human insulin and human growth hormone. Mean \pm SEM; $n=12 ; p$ versus preceding concentration: ${ }^{*}<0.02 ;^{* *}<0.002$; ${ }^{* * *}<0.001 .(-)=$ insulin $;(--)=$ growth hormone

\section{Local effects of insulin (Fig.1)}

At random, $80 \mathrm{mU}$ insulin dissolved in $2 \mu 1$ were injected into the proximal tibia growth plate of one leg and $2 \mu \mathrm{l}$ normal saline into the proximal tibia cartilage zone of the other leg. Thus, the individual rat served as its own control. Insulin treatment significantly $(p<0.05)$ increased the width of the proximal tibial growth plates compared to the saline injected contralateral leg.

\section{Cell cultures (Fig.2)}

The viability of the cells was $79 \pm 7 \%$ (Mean \pm SD, $n=12$ ). Under basal conditions, $48 \pm 13$ colonies grew from 1000 inserted cells. Thus, $6.1 \pm 1.7 \%$ of the inserted viable cells formed colonies. For each single cell preparation, the number of colonies from viable chondrocytes growing under basal conditions was designated as $100 \%$. The addition of $10 \%$ fetal calf serum augmented colony formation to $231 \pm 46 \%$ above baseline. The addition of human biosynthetic insulin or growth hor- 
mone to the culture medium increased colony formation in a bell-shaped fashion. A plateau was reached with $3.1-6.25 \mathrm{ng} / \mathrm{ml}$ insulin and $25-50 \mathrm{ng} / \mathrm{ml}$ growth hormone. With $200 \mathrm{ng} / \mathrm{ml}$ insulin or $400 \mathrm{ng} / \mathrm{ml}$, GH in the incubation medium, colony formation was less compared to peak values.

\section{Discussion}

The debate on how growth hormone stimulates skeletal growth is still controversial. It may act either by the generation of growth factors, such as the somatomedins or insulin, which in turn may enhance new cartilage formation or growth hormone may directly augment somatic growth. The somatomedin hypothesis is based on the observation that $\mathrm{GH}$, at least in high concentrations, had no effect on cartilage in vitro; while the growth hormone dependent somatomedins stimulated cartilage metabolism [8]. Recently, hypophysectomised rats were infused with pure insulin-like growth factor I or II, and somatic growth was augmented in a dose dependent manner [23, 24]. Others have observed no effect or only a slight increase in skeletal growth when hypophysectomised rats or hypopituitary dwarf mice were treated with crude somatomedin preparations or recombinant methionyl insulin-like growth factor I [25-27]. In the present study, the subcutanous injection of growth hormone increased body length, the width of the tibia growth plate, and the incorporation of sulfate into rib cartilage. Somatomedin activity was augmented, suggesting that $\mathrm{GH}$ induced skeletal growth is mediated at least in part by the somatomedins. Additionally, a direct enhancing effect of growth hormone in physiological concentrations on colony formation from isolated chondrocytes of rib cartilage has been demonstrated. The result is in accordance with a previous report, where $40 \mathrm{ng} / \mathrm{ml}$ of $\mathrm{GH}$ provoked a maximal response on colony formation from rat chondrocytes, while $160 \mathrm{ng} / \mathrm{ml}$ had no effect on cell growth [12]. Others were unable to confirm these results, which may be partially explained by the high $(5 \mu \mathrm{g} / \mathrm{ml})$ or inappropriate low $(5 \mathrm{ng} / \mathrm{ml}) \mathrm{GH}$ concentrations, which were used [21]. Interestingly, when the high doses of 1.2 or $2.4 \mathrm{U} \mathrm{GH}$ were injected into the tibia growth plates of rhesus monkeys, inhibition of the corresponding leg growth was observed compared to the saline injected contralateral leg [22]. Using the same technique in hypophysectomised rats, growth hormone in low concentrations increased the width of the tibia growth plate [10, 11]. The results suggest that growth hormone in physiological, but not pharmacological concentrations, directly augments growth of chondrocytes in vivo and in vitro. At present, it is unkown if the effect of $\mathrm{GH}$ on clonal growth might be dependent upon the production of growth factors in the chondrocytes themselves that promote growth by paracrine or autocrine mechanisms. Alternatively, growth hormone and IGF-I may stimu- late different populations of chondrocytes in growing cartilage [28].

Recently, the role of insulin as a growth factor has been reviewed in detail $[20,29]$. It was stated that the hormone in high doses increased replication of many cells, and that the insulin induced growth of cells may be exerted by its cross reaction with the IGF-I receptor, thereby promoting growth [20,29]. In the present study, the subcutaneous injection of $5 \mathrm{U}$ to $30 \mathrm{U}$ insulin per $\mathrm{kg}$ per day increased body length, the width of the tibia growth plate, and the incorporation of sulfate into rib cartilage. This is not a very high insulin dose for rats. In streptozotocin diabetic rats, 10 to $20 \mathrm{U}$ insulin $\cdot \mathrm{kg}^{-1}$. day $^{-1}$ were needed to normalise the elevated blood glucose concentrations [30]. In addition, in genetically determined diabetic BB rats, $15-18 \mathrm{U}$ insulin $\cdot \mathrm{kg}^{-1}$. day $^{-1}$ were used in the diabetic-prone animals to possibly prevent overt diabetes mellitus. It was stated that the high dose of $15-18 \mathrm{U}$ insulin $\cdot \mathrm{kg}^{-1} \cdot \mathrm{day}^{-1}$ was appropriate for these normoglycaemic rats [31]. In our study, serum somatomedin activity was not different between insulin- and saline-injected control animals, though the plasma insulin concentrations $24 \mathrm{~h}$ after the last insulin injection were grossly elevated. These results suggest, but do not prove, that insulin without the generation of the somatomedins directly increased longitudinal growth [29]. This conclusion was further supported by the observation that the local injection of insulin into the proximal tibia growth plate significantly enhanced cartilage growth as compared to the saline injected contralateral leg which served as the control. Furthermore, insulin in physiological, but not pharmacological concentrations, augmented growth of chondrocytes in the cell culture experiments. Finally, the important question the contribution of insulin in relation to growth hormone on postnatal growth is difficult to answer, since extensive dose-response studies are lacking. Salter and Best [1] claimed, that insulin and growth hormone were equally potent in augmenting longitudinal growth, while others reported a rather small or insignificant effect of insulin compared to growth hormone $[32,33]$. One can only speculate, if the additional replacement therapy with cortisone acetate in the latter two studies, which was not used in the present experiments or by Salter and Best [1], might explain some of the apparent differences.

Acknowledgements. The authors wish to thank H. Pinzer, E. Kley, and M. Schulz for expert technical helps and F.Schmelcher for preparing the manuscript. Dedicated to Walter Teller on the occasion of his 60 th birthday. Supported by Deutsche Forschungsgemeinschaft (He 609/1-1) Bad Godesberg, FRG.

\section{References}

1. Salter J, Best C (1953) Insulin as a growth hormone. Br Med J 2: 353-356

2. Penhos JC, Castillo L, Voyles N, Gutman R, Lazarus L, Recant L (1971) Decreased glucose tolerance in the rat following hypophysectomy. Endocrinology 88: 1141-1149 
3. Kaufmann U, Zapf J, Froesch ER (1978) Growth-hormone dependence of non-suppressible insulin-like activity (NSILA) and of NISLA-carrier protein in rats. Acta Endocrinol (Copenh) 87: 716-727

4. Heinze E, Kleinert W, Fussgaenger RD (1981) Time course of impaired insulin secretion in hypophysectomized rats. Hormone Res 14: 243-249

5. Heinze E, Petersen JU, Vetter U, Schleyer M, Voigt KH (1983) Insulinsekretion nach Hypophysektomie. Act Endokrinol 4: 122

6. Maes M, Underwood LE, Ketelslegers JM (1986) Low serum somatomedin-C in insulin-dependent diabetes: evidence for a postreceptor mechanism. Endocrinology 118: 377-382

7. Eigenmann JE, Becker M, Kammermann B, Lehmann W, Heimann R, Zapf J, Froesch EF (1977) Decrease of nonsuppressible insulin-like activity after pancreatectomy and normalization by insulin therapy. Acta Endocrinol (Copenh) 85: 818-822

8. Van Wyk JJ, Underwood LE, Hintz RL, Clemmons DR, Voina SJ, Weaver RP (1974) The somatomedins: a family of insulin like hormones under growth hormone control. Recent Prog Horm Res 30: 259-318

9. Zapf J, Rinderknecht E, Humbel RE, Froesch ER (1978) Nonsuppressible insulin-like activity (NSILA) from human serum: recent accomplishments and their physiologic implications. Metabolism 27: 1803-1828

10. Isaksson OGP, Jansson JO, Ganse JAM (1982) Growth hormone stimulates longitudinal bone growth directly. Science 216: 1237-1239

11. Russel SM, Spencer EM (1985) Local injections of human or rat growth hormone or of purified human somatomedin-C stimulate unilateral tibia epiphyseal growth in hypophysectomized rats. Endocrinology 116: 2563-2567

12. Lindahl A, Isgaard J, Nilsson A, Isaksson OGP (1986) Growth hormone potentiates colony formation of chondrocytes in suspension culture. Endocrinology 118: 1843-1848

13. Zapf J, Schmid CH, Froesch ER (1984) Biological and immunological properties of insulin-like growth factors (IGF) I and II. Clin Endocrinol Metab 13:3-30

14. Baetzner P, Fehm HL, Voigt KH, Schleyer M, Pfeiffer EF (1972) Measurement of biological activity in various growth hormone preparations using a modified tibia test. Acta Endocrinol (Copenh) $70: 231-238$

15. Van den Brande JL, Du Caju MVL (1974) An improved technique for measuring somatomedin activity in vitro. Acta Endocrinol (Copenh) $75: 233-242$

16. Vetter U, Zapf J, Heit W, Helbing G, Heinze E, Froesch RE, Teller WM (nological properties of insulin-like growth factors (IGF) I and II. Clin Endocrinol Metab 13:3-30

17. Baetzner P, Fehm HL, Voigt KH, Schleyer M, Pfeiffer EF (1972) Measurement of biological activity in various growth hormone preparations using a modified tibia test. Acta Endocrinol (Copenh) 70:231-238

18. Van den Brande JL, Du Caju MVL (1974) An improved technique for measuring somatomedin activity in vitro. Acta Endocrinol (Copenh) 75: 233-242

19. Vetter U, Zapf J, Heit W, Helbing G, Heinze E, Froesch RE, Teller WM (1986) Human fetal and adult chondrocytes: effect of insulin-like growth factors I and II, insulin, growth hormone on clonal growth. J Clin Invest 77: 297-305

20. Heinze E, Vetter U (1987) Skeletal growth of fetuses from streptozotocin diabetic rat mothers: in vivo and in vitro studies. Diabetologia 30: 100-103

21. Hoskins JM, Menzelle GG, Sanders FK (1956) A comparison of methods for estimating the viable count of a suspension of tumor cells. Exp Cell Res 11: 297-305
22. Finney DF (1952) Statistical methods in biological methods. Griffin, London

23. Hill DJ, Milner RDG (1985) Insulin as a growth factor. Ped Res 19:879-886

24. Jones KL, Villela JF, Lewis UJ (1986) The growth of cultured rabbit articular chondrocytes is stimulated by pituitary growth factors but not by purified human growth hormone or ovine prolactin. Endocrinologe 118: 2588-2593

25. Malzowski S, Caruso-Nicoletti M, Ren SG, Udelsman R, Loriaux L, Cassorla F (1987) Growth hormone (GH) injections directly into an epiphyseal plate (EP) fail to stimulate linear growth in the rhesus monkey (RM). Ped Res 21 (2): 250 abstr 459

26. Schoenle E, Zapf J, Humbel RE, Froesch ER (1982) Insulinlike growth factor I stimulates growth in hypophysectomized rats. Nature 296: 252-253

27. Schoenle E, Zapf J, Hauri C, Steiner T, Froesch ER (1985) Comparison of in vivo effects of insulin-like growth factors I and II and of growth hormone in hypophysectomized rats. Acta Endocrinol (Copenh) 108: 167-174

28. Holder AT, Spencer EM, Preece MA (1981) Effects of bovine growth hormone and a partially pure preparation of somatomedin on various growth parameters in hypopituitary dwarf mice. J Endocrinol 89:275-282

29. Van Buul-Offers S, Van den Brande JL, Hoogerbrugge CM, Dumoleijn L, v.d. Klundert PLM (1979) Effect of growth hormone and peptide fractions containing somatomedin activity on growth and cartilage metabolism of snell dwarf mice. Acta Endocrinol 92: 242-257

30. Skottner A, Clark RG, Robinson ICAF, Fryklund L (1987) Recombinant human insulin-like growth factor: testing the somatomedin hypothesis in Hypophysectomized rats. J Endocrinol 112: $123-132$

31. Lindahl A, Isgaard J, Carlsson L, Isaksson OGP (1987) Differential effects of growth hormone and insulin-like growth factor I on colony formation of epiphyseal chondrocytes in suspension culture in rats of different ages. Endocrinology 121: 1061-1069

32. Froesch ER, Zapf J (1985) Insulin-like growth factors and insulin: comparative aspects. Diabetologia 28: 485-493

33. Rasch R (1979) Control of blood glucose levels in the streptozotocin diabetic rat using a long acting heat-treated insulin. Diabetologia 16: 185-190

34. Gotfredsen CF, Buschard K, Frandsen EK (1985) Reduction of diabetes incidence of BB Wistar rats by early prophylactic insulin treatment of diabetes-prone animals. Diabetologia 28: 933-935

35. Ahren K (1959) Effect of insulin on body growth and mammary gland development in force-fed hypophysectomized rats injected with ovarian hormones. Acta Endocrinol 30: 593-598

36. Gause I, Isaksson O, Lindahl A, Eden S (1985) Effect of insulin treatment of hypophysectomized rats on adipose tissue responsiveness to insulin and growth hormone. Endocrinology 116: 945-951

Received: 15 September 1989

and in revised form: 14 January 1989

Prof. Dr. Eberhard Heinze

Universitäts-Kinderklinik

Prittwitzstraße 43

D-7900 Ulm/Donau

FRG 